\title{
Maciej Stępka*
}

\section{W poszukiwaniu odpowiedzi na wspótczesne kryzysy. Ewolucja rezyliencji w polskim dyskursie strategicznym (2007-2020) ${ }^{* *}$}

\author{
Searching for solutions to contemporary crises. \\ The evolution of resilience in the Polish strategic discourse (2007-2020)
}

\begin{abstract}
Streszczenie: Rezyliencja, rozumiana jako zdolność do przetrwania i adaptacji do sytuacji kryzysowych, dostarcza inspiracji do zmiany sposobu myślenia o bezpieczeństwie i współczesnych zagrożeniach. Celem niniejszego artykułu jest przeanalizowanie ewolucji i specyfiki myśli rezyliencyjnej w polskim dyskursie strategicznym. W artykule zostało wykorzystane podejście ramowo-narracyjne, oparte na materiale tekstowym pozyskanym z polskich strategii bezpieczeństwa narodowego oraz dokumentów o charakterze strategicznym, opublikowanych w latach 2007-2020. Wyniki analizy wskazują, że polskie podejście do rezyliencji ma konserwatywny charakter i bazuje głównie na strategii „utrzymania” status quo państwa w trakcie kryzysu. Do najważniejszych wątków rezyliencyjnych należa ochrona i odporność infrastruktury krytycznej; rozproszenie i upowszechnienie odpowiedzialności za bezpieczeństwo wśród organizacji społecznych i podmiotów prywatnych oraz budowa rezyliencji wspólnotowej, rozumianej jako zwiększenie zdolności odpornościowych obywateli i ich najbliższej wspólnoty. Polska myśl strategiczna marginalizuje elementy adaptacyjne i rekonstrukcyjne, skupiając się głównie na wzmacnianiu odporności poszczególnych elementów państwa. Polskie podejście do rezyliencji nadal wymaga uszczegółowienia, najlepiej w postaci wyspecjalizowanej strategii dotyczącej zwiększenia zdolności odpornościowych i adaptacyjnych państwa.
\end{abstract}

Słowa kluczowe: rezyliencja, kryzysy, polski dyskurs strategiczny

* Maciej Stępka - dr, Uniwersytet Jagielloński, Polska, ORCID: https://orcid.org/0000-0002-22298499, e-mail: maciek.stepka@uj.edu.pl.

** Artkuł powstał w wyniku realizacji projektu pt.,Rezyliencja (resilience) jako paradygmat bezpieczeństwa w czasach pandemii COVID-19. Przypadek Rzeczypospolitej Polskiej" finansowanego ze środków konkursu SocietyNow!\#1 w ramach programu Inicjatywa Doskonałości w Uniwersytecie Jagiellońskim. 


\begin{abstract}
Resilience, understood as an ability to withstand adapt to crisis situations, has been motivating a shift in the way of thinking about security and contemporary threats. The aim of this article is to analyze the evolution and characteristics of resilience in the Polish strategic discourse. The article applies the frame-narrative approach, building on textual material obtained from the national security strategies of Poland and strategic documents published between 2007-2020. The results of the analysis show that the Polish approach to resilience is conservative and focused on "maintaining" the status quo of the state in times of crisis. The Polish approach to resilience in centered on: the protection of critical infrastructure; dispersion of responsibility for security among social organizations and private entities; and building community resilience, understood as increasing the capacity of citizens and their immediate community to withstand and absorb shocks caused by crises. The Polish strategic thought marginalizes adaptive and reconstructive features of resilience, focusing on physical protection of vital elements the state. The Polish approach requires a more detailed framework for resilience, preferably in the form of a specialized strategy.
\end{abstract}

Keywords: resilience, crises, Polish strategic discourse

\title{
Wprowadzenie
}

Kryzys klimatyczny, ,kryzys migracyjny” czy pandemia COVID-19 obnażyły ograniczone możliwości nawet najbardziej rozwiniętych państw czy organizacji międzynarodowych w zakresie efektywnego antycypowania i reagowania kryzysowego, wymuszając tym samym zmianę w sposobie myślenia o bezpieczeństwie i przyszłych zagrożeniach. $\mathrm{Z}$ tego powodu w debatach tak akademickich, jak i politycznych coraz większą popularność zyskuje koncepcja rezyliencji ${ }^{1}$ (resilience), ujmowana jako odpowiedź na stale zmieniające się i niepewne środowisko bezpieczeństwa ${ }^{2}$. W szerokim ujęciu rezyliencja definiowana jest jako umiejętność przetrwania jednostek lub systemów (np. ekologicznych, społecznych czy politycznych) w szybko zmieniającym się świecie, naznaczonym niezwykle złożonymi i niemożliwymi do przewidzenia kryzysami ${ }^{3}$. Jest to koncepcja, która proponuje odejście od przekonania, że nadchodzące kryzysy można ominąć czy nawet nimi efektywnie zarządzać. W zamian promuje alternatywne podejście do

1 W niniejszym artykule wykorzystywany jest upowszechniony w socjologii, psychologii i pedagogice zwrot „rezyliencja”. Zdaniem autora, ten termin jest aktualnie najlepszą próbą ujęcia tej koncepcji, gdyż - w przeciwieństwie do tłumaczeń takich, jak "odporność" czy „sprężystość" nie redukuje jej znaczenia i odzwierciedla wewnętrzną złożoność koncepcji.

2 M. Dunn Cavelty, T. Prior, Resilience in Security Policy: Present and Future ${ }_{\prime \prime}$ CSS Analysis in Security Policy" 2013, no. 142, S. 1-4.

3 P. Bourbeau, Resiliencism: Premises and Promises in Securitisation Research ${ }_{\prime \prime}$ Resilience," vol. 1, 2013, no. 1, S. 3-17. 
bezpieczeństwa, oparte na rozbudowie szeroko rozumianych zdolności odpornościowych, umożliwiających absorbowanie szoków wywołanych przez kryzysy, adaptację, odbudowę oraz ciągłą pracę na rzecz wzmacniania najsłabszych ogniw w celu zwiększenia szans na przetrwanie systemu jako całości.

Wraz z początkiem XXI w. państwa oraz organizacje międzynarodowe zaczęły wykorzystywać rezyliencję, włączając elementy odpornościowe i adaptacyjne do swoich doktryn bezpieczeństwa, często tworząc własne strategie działań na poziomie lokalnym, centralnym i w końcu międzynarodowym. Takie organizacje, jak Unia Europejska czy NATO jasno opowiedziały się za wprowadzeniem działań na rzecz szerzenia rezyliencji wśród państw członkowskich i partnerskich $^{4}$. Na poziomie państwowym silne wątki rezyliencyjne można odnaleźć w strategiach bezpieczeństwa Stanów Zjednoczonych, Wielkiej Brytanii czy Singapuru ${ }^{5}$. Problematyka rezyliencji w kontekście polskiego dyskursu bezpieczeństwa stanowi pewną lukę badawczą. Wprawdzie polska strategia bezpieczeństwa narodowego z $2020 \mathrm{r}$. wyraźnie wskazała na rezyliencję jako komponent narodowego podejścia do bezpieczeństwa, jednak niejasne jest, jak ta koncepcja ewoluowała w polskiej myśli strategicznej i jakie dokładnie cechy posiada polskie podejście do rezyliencji.

Celem niniejszego artykułu jest ukazanie, w jaki sposób Polska interpretuje i operacjonalizuje rezyliencję w poszczególnych strategiach bezpieczeństwa narodowego Rzeczypospolitej Polskiej (RP). W artykule wykorzystano podejście interpretatywne, budując na jakościowej analizie ramowo-narracyjnej ${ }^{6}$. Podejście to skupia się na sposobie, w jaki określony aktor podchodzi do niektórych aspektów postrzeganej rzeczywistości, promując definicję konkretnego proble$\mathrm{mu}$, interpretację przyczynową, ocenę moralną i/lub działania zarad-

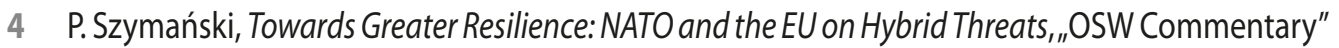
2020, nr 328, s. 5-10.

5 M. Dunn Cavelty, T. Prior, Resilience..., s. 2.

6 Podejście ramowo-narracyjne pozwala na zidentyfikowanie schematów, które mają za zadanie połączenie i umocnienie określonych wątków interpretacyjnych w szeroko rozumianym dyskursie. W niniejszym artykule rezyliencyzm stanowi pewien schemat bezpieczeństwa, przez pryzmat którego badany jest polski dyskurs strategiczny. Zob. M. Rein, D. Schön, Frame-Critical Policy Analysis and Frame-Reflective Policy Practice ,"Knowledge and Policy”, vol. 9, 1996, no. 1, s. 89-90. 
cze w ramach określonego dyskursu . Element narracyjny pozwala na wyszczególnienie wątków, które spajają dyskurs strategiczny i elementy rezyliencyjne w logiczną całość. Dzięki temu możliwe jest zobrazowanie i przeanalizowanie, jaki typ diagnozy środowiska bezpieczeństwa sprzyja wprowadzaniu elementów rezyliencyjnych w polskim dyskursie strategicznym; w jaki sposób uzasadniano wprowadzenie konkretnych rozwiązań rezyliencyjnych; i jaki mają one charakter. Do celów analizy wykorzystano materiał tekstowy pozyskany z: 1) strategii bezpieczeństwa narodowego RP opublikowanych w latach 2007-2020 ${ }^{8}$, stanowiących główne źródło danych, 2) innych dokumentów o randze strategicznej (np. Strategia rozwoju systemu bezpieczeństwa RP do 2022 czy Biała księga bezpieczeństwa narodowego), stanowiące materiał uzupełniający.

Artykuł został podzielony na trzy sekcje. W pierwszej części dokonany został przegląd teorii rezyliencji z uwzględnieniem dyskusji nad jej naturą i zastosowaniem w szeroko rozumianych studiach nad bezpieczeństwem. W kolejnej sekcji artykułu przeprowadzona została analiza poszczególnych strategii bezpieczeństwa RP. Ta część poświęcona jest omówieniu wątków rezyliencyjnych, które zostały wprowadzone do dyskursu strategicznego i skupia się przede wszystkim na sposobie ich uzasadnienia i operacjonalizacji. W trzeciej i ostatniej sekcji artykułu zaprezentowane zostały wnioski końcowe, uwzględniające krytyczną refleksję nad polskim podejściem do rezyliencji.

\section{Rezyliencja - główne założenia teoretyczne}

- Teoretyczne założenia rezyliencji zostały w znacznej mierze ukształtowane przez ekologię i badania nad równowagą i stabilnością ekosystemów, psychologię, pedagogikę i szereg prac poświęconych adaptacji i odporności psychicznej ${ }^{9}$. W studiach politologicznych i nad bezpieczeństwem, rezyliencja stała się popularnym motywem w ba-

7 R. Entman, Framing: Toward Clarification of a Fractured Paradigm, „Journal of Communication", vol. 43, 1993, no. 4, S. 52.

8 Cezura czasowa wynika ze wstępnej analizy materiału, która wskazała, że wcześniejsze strategie bezpieczeństwa narodowego RP jedynie w ograniczonym stopniu odnosiły się do rezyliencyzmu.

9 B. Lucini, Disaster Resilience from a Sociological Perspective: Exploring Three Italian Earthquakes as Models for Disaster Resilience Planning, Cham 2014, S. 32. 
daniach nad kryzysami, katastrofami i ryzykiem ${ }^{10}$. Paradygmat rezyliencyjny wskazuje na nieprzewidywalność środowiska bezpieczeństwa i nieuchronność nadchodzących kryzysów i kataklizmów, którym nie można zapobiec, lecz można spróbować się na nie przygotować, budując odpowiednie zdolności antycypacyjne, odpornościowe i adaptacyjne $^{11}$. W tym ujęciu rezyliencja przedstawiana jest jako pewna forma elastyczności i wytrwałości, odzwierciedlona w kulturze gotowości i zdolności do adaptacji i przetrwania określonych obiektów, które często funkcjonują w napięciu i długotrwałych okresach nacechowanych niepewnością i niestabilnością ${ }^{12}$. Literatura przedmiotu definiuje cały szereg podejść do rezyliencji, podkreślając jej pasywny (np. kultura antycypacji i gotowości) i aktywny (np. zdolności adaptacyjne i rekonstrukcyjne) charakter czy skupiając się na potencjale transformacyjnym w okresie pokryzysowym ${ }^{13}$. Na potrzeby artykułu wykorzystane zostały dwa typy rezyliencji, które są najczęściej uwzględniane w strategiach bezpieczeństwa: 1) rezyliencja systemowa ${ }^{14}$, obejmująca techniczny rozwój mechanizmów skupiających się na zwiększaniu szeroko rozumianej odporności i elastyczności systemów istotnych z punktu widzenia bezpieczeństwa, 2) rezyliencja wspólnotowa, polegająca na zwiększeniu odporności i umiejętności adaptacyjnych obywatela i jego wspólnoty oraz zwiększeniu jego roli w działaniach na rzecz reagowania kryzysowego i odbudowy ${ }^{15}$. Dodatkowo zostaną omówione dwie często spotykane strategie rezyliencyjne, tj. „utrzymanie” (maintenance) oraz „marginalna adaptacja” (marginality), które $\mathrm{w}$ różnym stopniu wpisują się w wyżej wspomniane typy ${ }^{16}$.

10 M. Dunn Cavelty, M. Kaufmann, K. Søby Kristensen, Resilience and (in)Security: Practices, Subjects, Temporalities, ,ISecurity Dialogue", vol. 46, 2015, no. 1, S. 3-14.

11 Ibidem, s. 9.

12 A. Gruszczak. Resilience and Mitigation in Security Management: Concepts and Concerns, "Forum Scientiae Oeconomia", vol. 4, 2016, no. 1, S. 12.

13 Ibidem, s. 8-13.

14 Także ujmowana w kategoriach rezyliencji ekologicznej lub technicznej.

15 M. Stępka, Rezyliencja jako paradygmat bezpieczeństwa w czasach przewlekłych kryzysów „„Przegląd Politologiczny", t. 26, 2021, nr 2, s. 107-110.

16 Istnieje także strategia "transformacyjna", przewidująca radykalną adaptację i zmiany w fundamentalnych aspektach funkcjonowania systemu dokonywanych w celu lepszego dostosowania się do sytuacji kryzysowych. Nie jest to jednak strategia istotna z punktu widzenia niniejszego artykułu. 
Według Hollinga, system o wysokim stopniu rezyliencji charakteryzuje się zdolnością do utrzymania swoich podstawowych cech i funkcjonalności mimo utraty stabilności spowodowanej ciągłymi lub incydentalnymi zakłóceniami ${ }^{17}$. W ujęciu systemowym rezyliencja opiera się na trwałości relacji układów w określonym systemie, stanowiącej miarę zdolności tych układów do absorpcji zmian wpływających na ich stan, oraz na zmiennych, które nim sterują ${ }^{18}$. Systemy o wysokim stopniu rezyliencji pozwalają na rozłożenie napięć pomiędzy komponentami w taki sposób, aby zabezpieczyć fundamentalne elementy i funkcje systemu i zapewnić ich przetrwanie $\mathrm{w}$ „trybie awaryjnym" do momentu pojawienia się warunków sprzyjającym "odbiciu się" (bounce back) do pożądanego stanu sprzed kryzysu' ${ }^{19}$. W tym kontekście teoria rezyliencyjna zwraca uwagę na potrzebę ochrony krytycznych elementów systemu oraz stałe wzmacnianie jego najsłabszych i najbardziej podatnych na zakłócenia punktów. Zgodnie z logiką rezyliencyjną, aby złagodzić negatywne skutki występowania "najsłabszych ogniw”, system powinien cechować się pewną elastycznością, funkcjonować na zasadzie subsydiarności, a jego poszczególne elementy powinny być gotowe do wspierania się nawzajem w sytuacjach krytycznych ${ }^{20}$.

Współczesne strategie rezyliencyjne promowane przez NATO, Stany Zjednoczone czy Wielką Brytanię w dużej mierze wykorzystują perspektywę systemową, skupiając się na ochronie status quo i szeroko rozumianej infrastruktury krytycznej w trakcie trwania przewlekłych, często pozamilitarnych kryzysów ${ }^{21}$. W literaturze rezyliencyjnej tego typu podejście określane jest jako strategia „utrzymania”, skupiająca się głównie na zapewnieniu ciągłości świadczenia niezbędnych usług publicznych oraz funkcjonowania rządu, przede wszystkim w kontekście jego zdolności do podejmowania decyzji, ich komunikowania i egzekwowania w sytuacjach kryzysowych ${ }^{22}$. „Utrzymanie” przewiduje silne wsparcie tych obszarów funkcjonowania państwa, które są naj-

C.S. Holling, Resilience and Stability of Ecological Systems, „Annual Review of Ecology and Systematics", vol. 4, 1973, no. 1, s. 2-3.

18 Ibidem, s. 27.

19 A. Wildavsky, Searching for Safety, New Brunswick, London 1988, s. 77.

20 B.S. Manyena, The Concept of Resilience Revisited ,"Disasters", vol. 30, 2006, no. 4, S. 437.

21 M. Dunn Cavelty, T. Prior, Resilience..., s. 2-3.

22 P. Bourbeau, Resiliencism..., s. 8. 
bardziej podatne na zakłócenia (np. infrastruktura energetyczna czy transportowa) i/lub wymykają się poza tradycyjnie rozumianą kontrolę państwa (np. cyberprzestrzeń, w tym media społecznościowe) ${ }^{23}$. W celu zapewnienia odporności obszarów krytycznych, strategie rezyliencyjne często odnoszą się do potrzeby rozproszenia odpowiedzialności za bezpieczeństwo i zwiększenia partnerstwa pomiędzy podmiotami państwowymi i prywatnymi.

Kolejną istotną strategią rezyliencyjną jest podejście adaptacyjne. Przykładem tego może być tzw. „marginalna adaptacja”, która przewiduje łagodzenie negatywnych skutków kryzysu poprzez wprowadzanie zmian na marginesie systemów społeczno-politycznych, bez podważania ich podstawowych cech i funkcjonalności ${ }^{24}$. W tym ujęciu domyślne mechanizmy reagowania kryzysowego są bardziej elastyczne w swoich działaniach, otwierając się na możliwość szybkiego dostosowania się do dynamicznie zmieniającej się sytuacji kryzysowej $^{25}$. Zdolność do adaptacji odzwierciedla, jak szybko i w jaki sposób dany podmiot uczy się na własnych błędach i umiejętnie wprowadza rozwiązania, które w przeszłości sprawdzały się w określnym kontekście społeczno-politycznym (np. w trakcie wojny, wielkich katastrof naturalnych). Jedną z istotniejszych cech tego typu strategii jest umiejętność innowacyjnego rozwiązywania zaistniałych problemów oraz samoorganizowanie się określonego systemu w sytuacjach, które wymagają szybkiego uzupełniania poszczególnych usług i zadań publicznych.

Elementy adaptacyjne są silnie akcentowane w rezyliencji wspólnotowej, która odnosi się do promocji szeroko zakrojonej kultury gotowości w społeczeństwie, opartej na powszechnej zdolności wspólnot do absorpcji wszelkich szoków i adaptacji do nowych warunków kryzysowych ${ }^{26}$. Rezyliencja wspólnotowa przenosi i rozprasza odpowiedzialność w ramach systemu bezpieczeństwa „z rządu centralnego na poziom gminy, z wymiaru krajowego na lokalny, z służb bezpieczeń-

23 Ibidem.

24 Ibidem, s. 14.

25 D. Chandler, Resilience and the End(s) of the Politics of Adaptation, „Resilience”, vol. 7, 2019, no. 3, S. 305-311.

26 B.S. Manyena, The Concept..., s. 439. 
stwa na obywateli"27. W ten sposób stawia jednostkę i jej najbliższą wspólnotę w centrum polityki bezpieczeństwa. Wspólnotowy wymiar rezyliencji skupia się na zdolności wspólnot do radzenie sobie w sytuacjach kryzysowych, rozwijania zasobów materialnych, fizycznych, społeczno-politycznych i psychologicznych, które mają na celu promować bezpieczeństwo ich członków i chronić przed długotrwałymi efektami kryzysów ${ }^{28}$. Strategie rezyliencyjne w wymiarze wspólnotowym często skupiają się na wypracowaniu mechanizmów, które pozwalają na nabywanie odporności kolektywnej i umiejętności adaptacyjnych oraz wypracowanie i wprowadzenie rozwiązań zapewniających przetrwanie i w dalszej perspektywie pozytywną trajektorię rozwoju dla całej wspólnoty ${ }^{29}$.

Wiele współczesnych strategii bezpieczeństwa wskazuje obronę cywilną i obronę powszechną jako główne instrumenty pozwalające na zwiększenie poziomu rezyliencji wspólnotowej w państwie. Poprzez regularne szkolenia z zakresu obronności i szeroko rozumianego reagowania kryzysowego obywatele i obywatelki mają nabyć kompetencje, które pozwolą im odpowiednio zachować się w sytuacjach kryzysowych, np. wesprzeć wyspecjalizowane jednostki ratownicze czy stworzyć system wzajemnego wsparcia w trakcie trwania kryzysów ${ }^{30}$. Najnowszy dyskurs rezyliencyjny często wykracza poza wąski zakres szkoleń i edukacji na rzecz obronności. Wiele programów prorezyliencyjnych wskazuje na potrzebę wspierania inicjatyw oddolnych i szerzenia postaw solidarnościowych wśród obywateli, propagując wolontariat, dobre praktyki z zakresu pierwszej pomocy czy edukując społeczeństwo na temat odporności psychicznej i traumy pourazowej $^{31}$. W ramach rezyliencji wspólnotowej zwraca się także uwagę na potrzebę ochrony grup wrażliwych (np. dzieci i seniorów), które najciężej odczuwają skutki przewlekłych kryzysów ${ }^{32}$.

32 M. Dunn Cavelty, T. Prior, Resilience..., s. 2. 


\section{Budowanie ramy rezyliencyjnej . w polskim dyskursie strategicznym}

Pierwsze wyraźne wątki rezyliencyjne w polskim dyskursie strategicznym można dostrzec w Strategii bezpieczeństwa narodowego RP z 2007 r., która niewątpliwie uwzględniła elementy rezyliencji systemowej, wspólnotowej i konsekwentnego wzmacniania najsłabszych ogniw polskiego systemu bezpieczeństwa. Dokument podkreśla wagę odporności infrastruktury krytycznej, tj. strategicznie istotnych, wrażliwych i silnie ze sobą powiązanych obszarów bezpieczeństwa, takich jak cyberprzestrzeń, gospodarka, energetyka czy infrastruktura transportowa $^{33}$. Równocześnie odnosi się do strategii „utrzymania”, czyli zabezpieczenia akceptowalnego poziomu bezpieczeństwa poprzez gromadzenie rezerw materiałowych i zwiększanie odporności poszczególnych elementów systemu na zakłócenia wywoływane przez kryzysy (np. poprzez utrzymanie równowagi finansowej, stabilności energetycznej i surowcowej) ${ }^{34}$. Rezyliencja i strategia „utrzymania” wyraźnie promowane są w kontekście infrastruktury telekomunikacyjnej, często poddawanej odziaływaniom destabilizującym i destrukcyjnym $^{35}$. Dokument podkreśla, że niezbędne jest „redukowanie jej podatności na to oddziaływanie, minimalizowanie skutków ewentualnych ataków oraz przywrócenie w krótkim czasie stanu pełnej jej funkcjonalności”36. Ma być to osiągnięte dzięki rozszerzeniu odpowiedzialności za utrzymanie i ochronę infrastruktury telekomunikacyjnej o „producentów i dostawców urządzeń informatycznych oraz oprogramowania, krajowych operatorów telekomunikacyjnych, dostawców usług internetowych"37.

Strategia z 2007 r. wskazuje także na potrzebę „umacniania zdolności właściwych instytucji i organów państwa, wchodzących w skład systemu do prognozowania rozwoju sytuacji międzynarodowej i wewnętrznej oraz do wczesnego wykrywania wszelkich zmian negatywnie wpływających na bezpieczeństwo Polski" ${ }^{38}$. Stawia na responsyw- 
ność i elastyczność systemów reagowania kryzysowego, które mają dynamicznie dostosowywać się do stale zmieniających się sytuacji kryzysowych, z konfliktem zbrojnym włącznie ${ }^{39}$. Zgodnie z duchem rezyliencyjnym, strategia odnosi się do rozproszonego podejścia do zarządzania kryzysowego, ukazując potrzebę zwiększania możliwości organizacyjno-technicznych systemu ochrony ludności o „współpracujące podmioty społeczne zdolne do realizacji zadań z zakresu ratownictwa" 40 . W tym kontekście dokument pośrednio nawiązuje do rezyliencji wspólnotowej i zwiększenia kompetencji wspomnianych podmiotów społecznych, podkreślając ważną rolę edukacji obywatelskiej dzieci, młodzieży i dorosłych, mediów publicznych, organizacji pozarządowych i samorządowych w szerzeniu wiedzy i umiejętności niezbędnych do racjonalnego i skutecznego działania w warunkach pokoju i w stanach nadzwyczajnych ${ }^{41}$.

Wraz z przyspieszeniem prac nad reformą i rozbudową doktryny bezpieczeństwa narodowego, polski dyskurs strategiczny zaczął wyraźniej odzwierciedlać prorezyliencyjny sposób myślenia. Od 2013 r. zwracano uwagę na jakościową zmianę w środowisku bezpieczeństwa, podkreślając „transsektorowy i asymetryczny charakter współczesnych zagrożeń" oraz nieprzewidywalność nadchodzących kryzysów ${ }^{42}$. W centrum myślenia rezyliencyjnego pozostały wątki ochrony wrażliwych elementów infrastruktury krytycznej czy zabezpieczenia rezerw materiałowych i strategicznych, uzupełniono je jednak o potrzebę walki z chronicznymi dysfunkcjami systemu bezpieczeństwa, które znacznie obniżają bezpieczeństwo i rezyliencję państwa. Przykładowo, Biała księga bezpieczeństwa narodowego z 2013 r. zwraca uwagę na niedostatki narodowego systemu ochrony ludności, akcentując istotne słabości np. w systemie ratownictwa czy słabości systemu ostrzegania przed kryzysami ${ }^{43}$. Podkreślano także zaniechania związane z ochroną najbardziej wrażliwych obszarów funkcjonowania państwa, wskazując „na potrzebę ochrony infrastruktury krytycznej oraz budowy nowo-

39 Ibidem, s. 15.

40 Ibidem, s. 28.

41 Ibidem, s. 35.

42 Strategia rozwoju systemu bezpieczeństwa narodowego Rzeczypospolitej Polskiej 2022, Warszawa 2013, S. 7.

43 Biała księga bezpieczeństwa narodowego Rzeczypospolitej Polskiej, Warszawa 2013, s. 10. 
czesnego systemu rezerw strategicznych, tak by podnieść odporność państwa na pozamilitarne i militarne zagrożenia, w tym na sytuacje nadzwyczajne i nieprzewidywalne zdarzenia" 44 .

Budując na tej krytyce, Strategia bezpieczeństwa narodowego RP z 2014 r. wprowadza odniesienia do strategicznej roli odporności państwa, kontynuuje wątki rezyliencji w ujęciu systemowym i wspólnotowym, równocześnie pogłębiając i poszerzając ich dotychczasowy zakres. Od 2014 r. polski dyskurs strategiczny zaczął wyraźniej zwracać uwagę na wrażliwość na kryzysy kolejnych pozamilitarnych sektorów bezpieczeństwa, takich jak produkcja żywności czy ochrona środowiska. W kontekście rezyliencyjnym bezpieczeństwo żywnościowe sprowadza się przede wszystkim do wypracowania „odporności produkcji rolnej na niekorzystne zjawiska i utrzymanie kontroli nad ważnymi dla bezpieczeństwa państwa działami gospodarki żywnościowej" ${ }^{45}$. W tym aspekcie silnie łączone jest z problemami zmiany klimatu, degradacją bioróżnorodności i nadmierną eksploatacją zasobów naturalnych, w tym wodnych ${ }^{46}$. Kontynuując wątek ekologii i odporności na zagrożenia, strategia zwraca uwagę na potrzebę rozwijania zdolności adaptacyjnych „do zmieniających się uwarunkowań klimatycznych i hydrologicznych, polegających na wdrożeniu nowych rozwiązań systemowych, ukierunkowanych między innymi na minimalizowanie skutków klęsk żywiołowych i ekstremalnych zjawisk pogodowych" ${ }^{47}$.

Wątki rezyliencji wspólnotowej można odnaleźć we fragmentach poświęconych edukacji na rzecz bezpieczeństwa, gdzie strategia wyraźnie odwołuje się do zasadniczej roli kultury gotowości, opartej na kształtowaniu „świadomości społecznej w zakresie rozumienia zagrożeń dla bezpieczeństwa” oraz „kompetencji pozwalających reagować na te zagrożenia w sposób świadomy i racjonalny" ${ }^{48}$. Edukacja na rzecz bezpieczeństwa uwzględnia także zwiększanie efektywności

44 Strategia rozwoju..., s. 71.

45 Strategia bezpieczeństwa narodowego Rzeczypospolitej Polskiej, Warszawa 2014, s. 41; We wcześniejszych strategiach bezpieczeństwa także odwoływano się do potrzeby utrzymania rezerw żywności lub wypracowania samowystarczalności produkcji rolnej w Polsce, jednak bez uwzględnienia dynamicznie zmieniających się warunków klimatycznych czy potrzeby adaptacji przemysłu rolnego do negatywnych skutków zmian klimatu.

46 Ibidem, s. 12.

47 Ibidem, s. 41.

48 Ibidem, s. 39. 
działania administracji publicznej w sprawach bezpieczeństwa, a także stałe podnoszenie kwalifikacji i doskonalenia zdolności do skutecznego reagowania na różnorodne zagrożenia. W tym zakresie, dokument podkreśla rolę mediów, których zadaniem jest budowanie i pogłębianie świadomości społecznej w zakresie identyfikowania i odpowiedniego reagowania na pojawiające się zagrożenia ${ }^{49}$. Tak rozumiane zwiększenie kompetencji adaptacyjnych i odpornościowych ma służyć stworzeniu ogólnospołecznego systemu wsparcia systemu ratownictwa i zacieśnieniu współpracy pomiędzy społecznymi i państwowymi organizacjami działającymi na rzecz ochrony ludności.

Jak wykazano wyżej, rezyliencja w różnym stopniu przewijała się w polskim dyskursie strategicznym już od 2007 r., jednak dopiero Strategia bezpieczeństwa narodowego RP z 2020 r. podjęła próbę bardziej spójnego ujęcia tej koncepcji w ramach rozdziału „Odporność państwa i obrona powszechna" ${ }^{50}$. Dokument w dużej mierze kontynuuje wątki rezyliencyjne zawarte we wcześniejszych strategiach, potwierdzając niepewny i nieprzewidywalny charakter środowiska bezpieczeństwa i potrzebę budowania odporności i zdolności adaptacyjnych państwa w odniesieniu do zagrożeń o charakterze hybrydowym ${ }^{51}$.

W ujęciu systemowym strategia tradycyjnie skupia się na utrzymaniu i ochronie infrastruktury krytycznej, proponując szeroki katalog potencjalnych zagrożeń stwarzających niebezpieczeństwo dla ciągłości funkcjonowania państwa. Dokument zwraca uwagę na potrzebę zwiększania odporności „przede wszystkim w zakresie: skutecznych dostaw energii, niekontrolowanego przepływu osób i relokacji ludności, gromadzenia, ochrony oraz zagospodarowania zasobów żywności i wody, zdolności do postepowania w przypadku wystąpienia zdarzeń o charakterze masowym, odpornych sieci telekomunikacyjnych i systemów teleinformatycznych, systemów informowania i ostrzegania ludności oraz wydolnego systemu transportowego" ${ }^{52}$. W kontekście wrażliwych sektorów bezpieczeństwa po raz pierwszy podkreślono

50 Strategia bezpieczeństwa narodowego Rzeczypospolitej Polskiej, Warszawa 2020, s. 15-17; w oficjalnym anglojęzycznym tłumaczeniu rozdział nosi tytuł "Resilience of the state and common civic defence".

51 Ibidem, s. 6, 13, 15 .

52 Ibidem, s. 16. 
potrzebę ochrony przestrzeni informacyjnej, rozumianej w wymiarze fizycznym (infrastruktura i sprzęt), wirtualnym (systemy i oprogramowanie) $\mathrm{i}$ - co istotniejsze - poznawczym (kognitywnym) ${ }^{53}$. W ujęciu poznawczym rezyliencja odnosi się do odporności społeczeństwa na kampanie dezinformacyjne, często prowadzone w mediach społecznościowych. W celu zwalczania podatności na tego typu zagrożenia strategia nawiązuje do współpracy z mediami informacyjnymi, obywatelami i organizacjami pozarządowymi, co ma na celu zwiększenie świadomości społecznej w zakresie bezpieczeństwa w przestrzeni informacyjnej ${ }^{54}$.

Z uwagi na pandemię COVID-19 ważnym elementem strategii stało się bezpieczeństwo zdrowotne. Dokument przyznaje, że skuteczna walka z kryzysami wywołanymi przez lekoodporne bakterie i wirusy wymaga kompleksowego systemu opieki zdrowotnej oraz efektywnego zaplecza diagnostycznego, zdolnego do szybkiego wykrywania zagrożeń epidemicznych ${ }^{55}$.W tym aspekcie zwraca uwagę na wydajność systemu ochrony zdrowia oraz struktur administracji publicznej, które mają zapewnić ciągłość i kompleksowość opieki nad pacjentami ${ }^{56}$. W kontekście walki z kryzysami zdrowotnymi istotną rolę mają odgrywać także edukacja i działania z zakresu profilaktyki zdrowotnej oraz rezerwy strategiczne, $\mathrm{w}$ tym środki ochrony, sprzętu medycznego, jak i dostępność personelu medycznego oraz wyspecjalizowanego personelu administracyjnego ${ }^{57}$.

W kontekście rezyliencji wspólnotowej strategia z 2020 r. zmierza jeszcze wyraźniej w kierunku rozproszenia odpowiedzialności za bezpieczeństwo państwa, promując „odporność na zagrożenia, poprzez tworzenie systemu obrony powszechnej, opartego na wysiłku całego narodu, oraz budowanie zrozumienia dla rozwoju odporności i zdolności obronnych Rzeczypospolitej Polskiej" ${ }^{\prime 8}$. Strategia podkreśla istotność pozamilitarnych działań ochronnych i proobronnych $\mathrm{w}$ wymiarze lokalnym, przede wszystkim $\mathrm{w}$ ujęciu elastycznego rea- 
gowania na zagrożenia dla bezpieczeństwa państwa w czasie pokoju, kryzysu i wojny. Rezyliencja wspólnotowa ma opierać się na kapitale społecznym budowanym „poprzez kształtowanie umiejętności współpracy, sieci formalnych i pozaformalnych organizacji społecznych oraz kształtowanie wspólnoty wartości w polskim społeczeństwie"59. Tym samym dokument akcentuje potrzebę pełnego wykorzystania potencjału państwa, definiując społeczności lokalne i instytucje rządowe, organizacje pozarządowe, placówki edukacyjne i samych obywateli jako instrumenty mające zapewnić wszechstronną odporność państwa na zagrożenia. Centralną rolę w kształtowaniu rezyliencji wspólnotowej ma odgrywać uniwersalny system obrony cywilnej, odpowiedzialny za wspieranie szeroko rozumianej ochrony populacji i „skupienie się na budowaniu zdolności systemu do ciągłej adaptacji i reagowania na zmieniające się wyzwania i zagrożenia" ${ }^{60}$.

\section{Podsumowanie}

Rezyliencja zdobywała coraz większe znaczenie w polskim dyskursie strategicznym wraz ze wzrostem niepewności i nieprzewidywalności środowiska bezpieczeństwa. Analiza ramowo-narracyjna strategii bezpieczeństwa RP ukazuje, że polska interpretacja rezyliencji wpisuje się w raczej konserwatywne i centralistyczne podejście, skupiające się na strategii „utrzymania” status quo i budowaniu odporności na zagrożenia hybrydowe i transsektorowe, przy jak najdłuższym zachowaniu jego oryginalnej formy oraz kluczowych funkcji. W ramach polskiego podejścia do rezyliencji można wyodrębnić trzy istotne wątki: utrzymanie i ochrona infrastruktury krytycznej i rezerw materiałowych; upowszechnienie działań na rzecz rezyliencji państwa i rozproszenie odpowiedzialności za bezpieczeństwo; oraz próba wypracowania rezyliencji wspólnotowej, opartej na społecznych strukturach odpornościowych.

Rezyliencja w polskim dyskursie strategicznym związana jest głównie z ochroną najbardziej wrażliwych na zakłócenia ogniw systemu bezpieczeństwa i utrzymania ich funkcjonalności w trakcie kryzysów 
militarnych i pozamilitarnych. Tradycyjnie w centrum uwagi stawia się infrastrukturę krytyczną i rezerwy strategiczne, które mają cechować się odpornością na zakłócenia i zdolnością do szybkiego odbudowywania swoich zasobów. W tym ujęciu strategie bezpieczeństwa promowały względnie stały katalog obszarów krytycznych (np. infrastruktura teleinformatyczna, energetyczna czy transportowa), poszerzając go o nowe sektory raczej w odpowiedzi na zaistniałe kryzysy aniżeli w antycypacji przyszłych zagrożeń. Przykładem może być kwestia bezpieczeństwa zdrowotnego. Problem wrażliwości i niewydolności polskiego systemu ochrony zdrowia był wielokrotnie podnoszony na łamach tekstów naukowych, eksperckich czy raportów Najwyższej Izby Kontroli' ${ }^{61}$. Jednak dopiero pandemia COVID-19 wymusiła wyraźniejsze włączenie ochrony zdrowia do dyskursu strategicznego i rezyliencyjnego, wskazując na natychmiastową potrzebę uodpornienia państwa i społeczeństwa na kryzysy epidemiczne i ich następstwa. Tego typu postawa nie w pełni wpisuje się w logikę rezyliencyjną, która powinna być proaktywna względem zagrożeń, zamiast skupiać się głównie na reagowaniu na aktualne problemy, które wymykają się spod kontroli państwa.

Kolejnym ważnym wątkiem rezyliencyjnym jest upowszechnienie działalności na rzecz zwiększenia odporności państwa. Poszczególne strategie bezpieczeństwa RP wskazują na konieczność poszerzenia katalogu aktorów, którzy mieliby brać czynny udział w działaniach ratowniczych czy obronnych. W tym aspekcie ważną rolę mają odgrywać podmioty prywatne, lokalne organizacje społeczne i struktury cywilne, które mają stać się częścią powszechnego systemu rezyliencyjnego, zwiększając responsywność mechanizmów reagowania kryzysowego czy wydolność i odporność infrastruktury krytycznej. Bardzo istotnym elementem tego wątku rezyliencyjnego jest tendencja do rozproszenia odpowiedzialności za bezpieczeństwo i zmobilizowania jak najszerszej grupy podmiotów, które byłyby w stanie wspólnie unieść obciążenia związane z zarządzaniem złożonymi i często przewlekłymi kryzysami. Aby tego typu rozproszenie odpowiedzialności spełniało swoje zadanie, potrzebna jest jasna struktura współpracy, ramy praw-

61 Najwyższa Izba Kontroli, System ochronyzdrowia w Polsce -stan obecny ipożądane kierunkizmian, Warszawa 2018. 
ne i organizacyjne, które pozwoliłyby na uporządkowanie działań na rzecz rezyliencji. Tego typu rozwiązań wyraźnie brakuje w aktualnym polskim porządku prawnym, co stanowi poważne uchybienie w kontekście polityki rezyliencyjnej ${ }^{62}$.

Wątek upowszechnienia odpowiedzialności za szeroko rozumiane bezpieczeństwo państwa silnie wiąże się z rezyliencją wspólnotową, która ma odzwierciedlać lokalny system wsparcia, oparty na spójności i kapitale społecznym, solidarności, wolontariacie czy pomocy sąsiedzkiej. Polski dyskurs strategiczny podkreśla rolę lokalnych struktur społecznych, organizacji proobronnych, edukacyjnych i innych podmiotów, które mają kształtować i promować kulturę wsparcia i gotowości wśród społeczności lokalnych oraz działać na rzecz budowania zdolności do stałej adaptacji do trudnych warunków kryzysowych. Strategia z 2020 r. w centrum tego typu działań stawia m.in. obronę cywilną, która ma mieć powszechny charakter. W tym aspekcie problematyczne mogą dwie kwestie. Pierwszą z nich jest potrzeba fundamentalnej reformy polskiego systemu obrony cywilnej, który podczas kryzysu COVID-19 udowodnił, że nie jest w stanie wykonywać swych podstawowych zadań. Kolejnym problemem jest brak dedykowanej struktury wsparcia (finansowej czy materialnej) organizacji prorezyliencyjnych oraz oddolnych inicjatyw, które miałyby sprzyjać rezyliencji wspólnotowej. W takiej sytuacji istnieje ryzyko, że wiele inicjatyw na rzecz wsparcia i budowy odporności będzie miało charakter ad hoc i w dłuższej perspektywie nie zakorzeni się w lokalnych strukturach reagowania kryzysowego.

Polska nadal ma przed sobą długą drogę do przebycia zanim stanie się państwem posiadającym silne cechy rezyliencyjne. O ile polski dyskurs rezyliencyjny w sposób konsekwentny promował odporność państwa, o tyle zasadniczo zmarginalizował wątki adaptacyjne i odbudowy zasobów, które są niezbędne z punktu widzenia efektywnej polityki rezyliencyjnej. Państwo rezyliencyjne musi umieć uczyć się na swoich błędach i dynamicznie dostosowywać do kryzysowych sytuacji. Wymaga to jednak zmiany sposobu myślenia o bezpieczeństwie na poziomie strategicznym i społecznym. Wiąże się to nie tylko z rozpro- 
szeniem odpowiedzialności za bezpieczeństwo, ale przede wszystkim z racjonalnym wykorzystaniem zasobów i ukierunkowaniem działań prorezyliencyjnych. Innymi słowy, Polska potrzebuje kompleksowej, wyspecjalizowanej strategii na rzecz rezyliencji, która jasno zdefiniowałaby cele, zakres działań oraz struktury współpracy pomiędzy poszczególnymi aktorami państwowymi i pozarządowymi. Niezbędnym elementem tego typu strategii powinna być m.in. edukacja na rzecz rezyliencji, która od wczesnych etapów szkolnych powinna skupiać się na wypracowaniu kultury gotowości, postaw solidarności społecznej oraz wiedzy na temat potencjalnych i nadchodzących zagrożeń. Rezyliencja nie powinna opierać się wyłącznie na wąsko rozumianej odporności państwa, lecz przede wszystkim na zdolności do adaptacji systemu i samych obywateli, którzy w sposób świadomy i zorganizowany będą w stanie przetrwać i rozwijać się we współczesnych czasach, tak wyraźnie nacechowanych niepewnością i przewlekłymi, również transsektorowymi zagrożeniami.

\section{Bibliografia}

Biała księga bezpieczeństwa narodowego Rzeczypospolitej Polskiej, Warszawa 2013.

Bourbeau P., Resiliencism: Premises and Promises in Securitisation Research, „Resilience”, vol. 1, 2013, no. 1.

Cavelty Dunn M., Kaufmann M., Søby Kristensen K., Resilience and (in)Security: Practices, Subjects, Temporalities, „Security Dialogue”, vol. 46, 2015, no. 1.

Cavelty Dunn M., Prior T., Resilience in Security Policy: Present and Future, "CSS Analysis in Security Policy" 2013, no. 142.

Chandler D., Resilience and the End(s) of the Politics of Adaptation, "Resilience", vol. 7, 2019, no. 3 .

Entman R., Framing: Toward Clarification of a Fractured Paradigm, „Journal of Communication", vol. 43, 1993, no. 4.

Gruszczak A., Resilience and Mitigation in Security Management: Concepts and Concerns, „Forum Scientiae Oeconomia”, vol. 4, 2016.

Holling C.S., Resilience and Stability of Ecological Systems, „Annual Review of Ecology and Systematics", vol. 4, 1973, no. 1.

Lucini B., Disaster Resilience from a Sociological Perspective: Exploring Three Italian Earthquakes as Models for Disaster Resilience Planning, Cham 2014 .

Manyena B.S., The Concept of Resilience Revisited, „Disasters”, vol. 30, 2006, no. 4. 
Najwyższa Izba Kontroli, System ochrony zdrowia w Polsce - stan obecny i pożadane kierunki zmian, Warszawa 2018.

Najwyższa Izba Kontroli, Wspótpraca Ministerstwa Obrony Narodowej z organizacjami proobronnymi, 25.03.2021, https://bit.ly/3ffsQuK.

Rein M., D. Schön, Frame-Critical Policy Analysis and Frame-Reflective Policy Practice, „Knowledge and Policy”, vol. 9, 1996, no. 1.

Stępka M., Rezyliencja jako paradygmat bezpieczeństwa w czasach przewlektych kryzysów, „Przegląd Politologiczny”, vol. 26, 2021, no. 2.

Strategia bezpieczeństwa narodowego Rzeczypospolitej Polskiej, Warszawa 2007.

Strategia bezpieczeństwa narodowego Rzeczypospolitej Polskiej, Warszawa 2014.

Strategia bezpieczeństwa narodowego Rzeczypospolitej Polskiej, Warszawa 2020.

Strategia rozwoju systemu bezpieczeństwa narodowego Rzeczypospolitej Polskiej 2022, Warszawa 2013.

Szymański P., Towards Greater Resilience: NATO and the EU on Hybrid Threats, „OSW Commentary” 2020, nr 328.

Wildavsky A., Searching for Safety, New Brunswick, London 1988. 